is part of it. Given one stanza with the germ of an idea, the free-wheeling imagination of the singers might lead them to add verse after verse. Such spontaneity gives these rustic rhymes a claim to a literary contribution of sorts.

As the 20th century got under way interest in the playparties waned. The young adults married and settled down, or drifted off to the towns where jobs looked tempting. The Cherokee Strip, just opening up, lured some to try their luck at farming on one of the last frontiers. The younger set, the kid party group, somehow got the notion that the old games were "countrified." They got up "socials," or "sociables." Guessing games and contests calling for a little brain work seemed more genteel. "Molly Brooks" and "Old Dan Tucker" were forgotten.

Tapes, I suppose, will preserve the music of the Rock and Roll generation for a later day, when someone may wish to study the subject. By that time "Do-wah, diddy diddy," or "Get Off of My Cloud" may sound as quaint as "Pig in the Parlor" sounds to one who never attended a play-party.

\title{
Union Sword Added To Historical Museum
}

A Union sword taken as a souvenier by Major William G. Thompson during a surprise raid the Major led against Corpus Christi, Feb. 21, 1864, has been added to the collection of Civil War swords on exhibit at the State Historical Museum, Des Moines. The sword was originally from the Federal gunboat "Sachem," having been taken by Confederate Captain Nolan when he captured the gunboat at Sabine Pass.

Captain Nolan was at Corpus Christie at the time of Major Thompson's raid. The Captain escaped the raiders but Union supplies, including the aformentioned sword, were found in his house.

The sword was donated to the Museum by William G. Thompson, Tenafly, N. J., grandson of Major Thompson.

(Selected Civil War Letters of Major Thompson were published in the Annals of lowa, Vol. 38, No. 6.) 
Copyright of Annals of Iowa is the property of State of Iowa, by \& through the State Historical Society of Iowa and its content may not be copied or emailed to multiple sites or posted to a listserv without the copyright holder's express written permission. However, users may print, download, or email articles for individual use. 